\title{
Plant growth and nutritional status of leaves from young grapevines grown in soil subjected to potassium and limestone applications
}

\author{
Crecimiento y estado nutricional en hojas de vides jóvenes \\ con aplicación de potasio y cal en el suelo \\ Marlise Nara Ciotta ${ }^{*}$, Carlos Alberto Ceretta ${ }^{2}$, Lincon Stefanello de Oliveira ${ }^{3}$, \\ Matheus Kulmann ${ }^{3}$, Paulo Ademar Avelar Ferreira ${ }^{3}$, Gustavo Brunetto ${ }^{3}$
}

\begin{abstract}
The aims of the current study are to (a) evaluate the growth and nutritional status of young Chardonnay and Pinot Noir vines grown in soil subjected to $\mathrm{K}$ application and (b) to determine the growth and nutritional status of young Chardonnay vines grown in soil subjected to $\mathrm{K}$ and to different limestone applications. The experiment was conducted in Red Argisol, in Santana do Livramento County (RS), in crop seasons from 2011/12 to 2013/14. Treatments adopted in experiment 1 comprised 0,30 and $60 \mathrm{~kg}$ of $\mathrm{K}_{2} \mathrm{O}$ $\mathrm{ha}^{-1}$. Variables $\mathrm{K}$ exchangeable content in the soil, $\mathrm{K}$ content in leaves, plant height, stem diameter and weight of the pruned material were evaluated. Treatments adopted in experiment 2 comprised $0,60,120$, and $180 \mathrm{~kg}$ of $\mathrm{K}_{2} \mathrm{O} \mathrm{ha}^{-1}$, as well as calcitic and dolomitic limestone applications. Variables exchangeable $\mathrm{K}, \mathrm{Ca}$ and $\mathrm{Mg}$ contents in the soil, $\mathrm{K}, \mathrm{Ca}$ and $\mathrm{Mg}$ contents in leaves, plant height, stem diameter and weight of the pruned material were evaluated. Potassium fertilization increased the K content in the $0-10 \mathrm{~cm}$ layer and influenced the $\mathrm{K}$ content in leaves collected in the first crop; however, it did not influence growth parameters in Chardonnay and Pinot Noir cultivars. Potassium, dolomitic and calcitic limestone application enabled nutrient absorption by plants, whose leaves presented increased K content; however, it did not influence growth parameters in cultivar Chardonnay.

Keywords: potassium fertilization, liming, leaf analysis, Vitis vinifera.
\end{abstract}

\section{RESUMEN}

Los objetivos de este estudio fueron: (a) evaluar el crecimiento y el estado nutricional de las vides jóvenes cv. Chardonnay y Pinot Noir cultivadas en suelos donde se incorporó $K ; y(b)$ determinar el crecimiento y el estado nutricional de plantas juveniles de vid cv. Chardonnay cultivadas en suelos donde se incorporó $K$ y diferentes dosis de cal. El experimento se realizó en Red Argisol, en el condado de Santana do Livramento (RS), en las temporadas de cultivo del 2011/12 al 2013/14. El tratamiento del Experimento 1 fue la incorporación de 0, 30 y $60 \mathrm{~kg}$ de $\mathrm{K}_{2} \mathrm{O} \mathrm{ha-1}$. Se evaluó el contenido de K intercambiable en el suelo, contenido de $\mathrm{K}$ en las hojas, altura de la planta, diámetro del tallo y peso del material podado. El tratamiento del Experimento 2 fue la incorporación de 0, 60, 120 y $180 \mathrm{~kg}$ de $\mathrm{K}_{2} \mathrm{O} \mathrm{ha}{ }^{-1}$, con aplicaciones de calcita y dolomita. Se evaluaron los contenidos de K, Ca y Mg intercambiables en el suelo, los contenidos de $\mathrm{K}$, Ca y Mg en las hojas, la altura de la planta, el diámetro del tallo y el peso del material podado. Los resultados del Experimento 1 sugieren que la fertilización con potasio aumentó el contenido de K en la capa de 0-10 cm e influyó en el contenido de $\mathrm{K}$ en las hojas recolectadas en el primer cultivo. Sin embargo, no afectó los parámetros de crecimiento en los cultivares Chardonnay y Pinot Noir. Los resultados del Experimento 2 muestran que la aplicación de potasio, calcita y dolomita permitió la absorción de nutrientes de las plantas jóvenes, cuyas hojas presentaron un mayor contenido de K. Sin embargo, no influyó en los otros parámetros de crecimiento en el cultivar Chardonnay, ni en el contenido de Ca y Mg en las variables estudiadas.

Palabras clave: fertilización potásica, encalado, análisis foliar, Vitis vinifera.

\section{Introduction}

Rio Grande do Sul State (RS) has approximately 50,000 ha planted with vines; it is the largest cultivated area in Brazil. Since the 1970s, part of the soil in natural fields in the Campanha Gaúcha region (Southwestern Rio Grande do Sul State) was incorporated to grapevine production systems such as Chardonnay and Pinot Noir, whose grapes are used to produce fine wines (Mello, 2010; Rodrigues,

\footnotetext{
Epagri - Experimental Station of Lages, Lages County, Santa Catarina State, Brazil, CEP 88.502-970.

Federal University of Santa Maria, Santa Maria Campus, Rio Grande do Sul State, Brazil.

Federal University of Santa Maria, Cachoeira do Sul Campus, Rio Grande do Sul State, Brazil.

Corresponding author: marlise@epagri.sc.gov.br
}

Fecha de Recepción: 19 de Agosto, 2019.

Fecha de Aceptación: 1 de Marzo, 2020. 
2018). Vineyards are often implemented in lowfertility sandy-texture Argisols, whose nutrient contents, such as potassium (K), are found at low and medium availability levels. Therefore, it is essential applying corrective agents and fertilizers to the soil before the planting process (pre-planting fertilization) and throughout the production period (maintenance fertilization). Potassic fertilizer application to soil surface in the entire field and its subsequent incorporation to approximately $20 \mathrm{~cm}$ down the soil are recommended as pre-planting fertilization strategy (CQFS-RS/SC, 2016; de Melo, et al., 2016). Young vines are transplanted to fertilized soil; therefore, it is not necessary performing new potassium fertilizer applications throughout the growth period, since potassium fertilizer applications in the pre-planting period supposedly increase the content of exchangeable $\mathrm{K}$ in the 20-cm layer. Consequently, this application increases $\mathrm{K}$ supply to the external surface of the roots, as well as its absorption (Fagan et al., 2016) and accumulation in growth-related organs such as the leaves (Tagliavini \& Scandellari, 2013). Thus, plants are expected to absorb and use K for selfdevelopment, since this nutrient leads to increased plant growth, which is a variable that can be measured through plant height, stem diameter or weight of the pruned material. However, the best $\mathrm{K}$ dose applied to increase the $\mathrm{K}$ content $20 \mathrm{~cm}$ down the soil (close to the sufficiency level of young vines), as well as the impact of such dose on K contents in the leaves and on plant growth parameters, mainly in sandy-texture soils presenting low cation exchange capacity (CEC), remain poorly know. On the other hand, magnesium $(\mathrm{Mg})$ deficiency symptoms can be observed in the leaves of young vines grown in soil presenting high exchangeable $\mathrm{K}$ content, and even in leaves presenting rachis desiccation, which is a physiological disorder affecting producing vines (Coombe, 1987; Christensen, 1991; Hall, 2011; Bachteler et al., 2013; Toumi et al., 2016). However, there is insufficient knowledge about whether the application of $\mathrm{K}$ doses to the soil, and the use of limestones capable of unbalancing the Ca: $\mathrm{Mg}$ ratio in it, can cause $\mathrm{Mg}$ deficiency in the tissue of plants grown in the soil and under climatic conditions of Campanha Gaúcha region. This deficiency can affect growth parameters such as plant height, stem diameter and weight of the pruned material (Pickering, 2005).The aims of the current study were to evaluate (a) the growth and nutritional status of young Chardonnay and Pinot Noir vines grown in soil subjected to potassium application and (b) to determine the growth and nutritional status of young Chardonnay vines grown in soil subjected to potassium, dolomitic and calcitic limestone application.

Experiments 1 and 2 were implemented in Santana do Livramento County, Campanha Gaúcha Region, Brazil (Latitude 30 49' 8' S and Longitude $55^{\circ} 27^{\prime} 3$ " W). The region presents Paleudalf soil (dos Santos et al., 2013), whose pre-experimental features in the $0-20-\mathrm{cm}$ layer comprises $94 \mathrm{~g} \mathrm{~kg}^{-1}$ clay, $12.0 \mathrm{~g} \mathrm{~kg}^{-1}$ organic matter, $\mathrm{pH} 5.0$ in water; $1.28 \mathrm{cmol}_{\mathrm{c}} \mathrm{kg}^{-1}$ exchangeable $\mathrm{Ca}, 1.1 \mathrm{cmol}_{\mathrm{c}} \mathrm{kg}^{-1}$ exchangeable $\mathrm{Mg}, 0.4 \mathrm{cmol}_{\mathrm{c}} \mathrm{kg}^{-1}$ exchangeable $\mathrm{Al}$ (extracted through $1 \mathrm{~mol} \mathrm{l}^{-1} \mathrm{KCl}$ ); $7.6 \mathrm{mg} \mathrm{kg}^{-1}$ available $\mathrm{P}$ and $80 \mathrm{mg} \mathrm{kg}^{-1}$ exchangeable $\mathrm{K}$ (both extracted through Mehlich-1); $2.7 \mathrm{cmol}_{\mathrm{c}} \mathrm{kg}^{-1}$ $\mathrm{CEC}_{\text {efective }}$ and $4.7 \mathrm{cmol}_{\mathrm{c}} \mathrm{kg}^{-1} \mathrm{CEC}_{\mathrm{pH} \text { 7.0. }}$. According to the Koppen's classification, the climate in the investigated region is subtropical humid, Cfa2 type, which presents mild temperature and well-distributed rainfall events throughout the year - mean annual rainfall $1,600 \mathrm{~mm}$, mean temperature in the hottest month (January) $23.8^{\circ} \mathrm{C}$ and mean temperature in the coldest month (July) $12.4{ }^{\circ} \mathrm{C}$. Table 1 shows the mean monthly temperature and rainfall data recorded during the experimental period.

\section{Experiment 1. Plant growth, and $K$ content in leaves of young Chardonnay and Pinot Noir vines grown in soil subjected to potassium application}

In August 2011, 3,800 kg ha-1 of dolomitic limestone was applied to soil surface and, subsequently, incorporated (through one plowing, one subsoiling and two harrowing procedures) to the 20 -cm layer in order to increase $\mathrm{pH}$ to 6.0 . In total, $60 \mathrm{~kg} \mathrm{ha}^{-1}$ of $\mathrm{P}_{2} \mathrm{O}_{5}$ (in the form of triple superphosphate), 80 $\mathrm{kg} \mathrm{ha}^{-1}$ of $\mathrm{N}$ (in the form of urea) and $40 \mathrm{~kg} \mathrm{ha}^{-1}$ of borax were applied to soil surface and incorporated (through one plowing, one subsoiling and two harrowing procedures) to the $20-\mathrm{cm}$ layer. Treatments consisted in the application of 0,30 and $60 \mathrm{~kg} \mathrm{ha}^{-1}$ of $\mathrm{K}_{2} \mathrm{O} . \mathrm{KCl}$ was the here in used $\mathrm{K}_{2} \mathrm{O}$ source. Potassium fertilizer doses were applied to soil surface and incorporated to the soil in two different stages, before vine transplantation. Half of each dose was applied to soil surface and incorporated to the soil based on the plowing technique. Subsequently, the 
Table 1. Mean rainfall, air temperature and sunshine per month in 2011, 2012 and 2013.

\begin{tabular}{|c|c|c|c|c|c|c|c|c|c|}
\hline \multirow{2}{*}{ Months } & \multicolumn{3}{|c|}{ Air temperature $\left({ }^{\circ} \mathrm{C}\right)$} & \multicolumn{3}{|c|}{ Rainfall (mm) } & \multicolumn{3}{|c|}{ Sunshine (hours) } \\
\hline & 2011 & 2012 & 2013 & 2011 & 2012 & 2013 & 2011 & 2012 & 2013 \\
\hline Jan & nd & 24.6 & 22.0 & nd & 18.7 & 158.2 & nd & 315.6 & 298.9 \\
\hline Feb & nd & 23.9 & 22.1 & nd & 220.5 & 84.2 & nd & 218.5 & 215.2 \\
\hline Mar & nd & 21.3 & 18.9 & nd & 58.5 & 73.9 & nd & 278.3 & 238.6 \\
\hline Apr & nd & 17.3 & 17.8 & nd & 147.5 & 120.7 & nd & 204.6 & 234.3 \\
\hline May & nd & 16.4 & 13.7 & nd & 13.1 & 200.6 & nd & 200.8 & 151.7 \\
\hline Jun & nd & 12.2 & 12.1 & nd & 77.7 & 42.7 & nd & 144.5 & 165.8 \\
\hline Jul & 10.4 & 9.5 & 11.7 & 127.4 & 32.2 & 68.7 & 161.2 & 203.1 & 216.8 \\
\hline Aug & 11.7 & 15.8 & 11.0 & 65.6 & 127.3 & 65.6 & 172.3 & 156.3 & 179.5 \\
\hline Sep & 14.7 & 15.4 & 14.7 & 119.4 & 156.1 & 119.6 & 233.0 & 190.0 & 179.8 \\
\hline Oct & 16.8 & 18.2 & 17.4 & 154.5 & 298.2 & 139.8 & 227.9 & 201.0 & 187.8 \\
\hline Nov & 20.4 & 21.5 & 20.1 & 54.1 & 58.0 & 283.1 & 283.2 & 286.6 & 239.9 \\
\hline $\operatorname{Dec}^{(1)}$ & 21.4 & 23.1 & 22.0 & 44.9 & 179.8 & 158.2 & 283.7 & 259.6 & 236.2 \\
\hline
\end{tabular}

(1). nd = non-determined.

second half of each dose was applied to the soil and incorporated to it based on the subsoiling technique. In October 2011, young Chardonnay and Pinot Noir vines (grafted onto the 110R rootstock) were transplanted to the experimental field and spaced 1.0 $\mathrm{m}$ from each other and $2.5 \mathrm{~m}$ between rows (4000 plants $\mathrm{ha}^{-1}$ ). In November 2014, soil samples were collected in the $0-10$ and $10-20-\mathrm{cm}$ layers in the crop row of each plant. The soil was air dried and sieved ( $2 \mathrm{~mm}$ mesh). Then, the exchangeable $\mathrm{K}$ was extracted (Mehlich-1 extractor) and determined in a flame photometer (Tedesco et al., 1995). In March 2012, 2013 and 2014, three leaves were collected in the median part of each plant, dried in forced air-circulation oven at $65^{\circ} \mathrm{C}$, ground and subjected to total K content analysis (Tedesco et al., 1995). In March 2012, the height of each plant was measured with measuring tape and the stem diameter $(10 \mathrm{~cm}$ above the surface of the soil) was measured with digital caliper. Winter pruning was carried out in July 2012 and 2013. The pruned material was dried in forced air-circulation oven at $65^{\circ} \mathrm{C}$ and, subsequently, the dry weight was recorded for each year. The stem diameter was measured with digital caliper in March 2013.

\section{Experiment 2. Plant growth, and $\mathrm{K}, \mathrm{Ca}$ and Mg content in leaves, of young Chardonnay vines grown in soil subjected to $K$, calcitic and dolomitic limestone application}

In August 2011, $60 \mathrm{~kg} \mathrm{ha}^{-1}$ of $\mathrm{P}_{2} \mathrm{O}_{5}$ (in the form of triple superphosphate), $80 \mathrm{~kg} \mathrm{ha}^{-1}$ of
$\mathrm{N}$ (in the form of urea) and $40 \mathrm{~kg} \mathrm{ha}^{-1}$ of borax were applied to soil surface and incorporated to the $20-\mathrm{cm}$ layer based on one subsoiling and on two harrowing procedures. Treatments consisted in the application of $0,60,120$ and $180 \mathrm{~kg} \mathrm{ha}^{-1}$ of $\mathrm{K}_{2} \mathrm{O}$, calcitic $\left(56.7 \mathrm{cmol}_{\mathrm{c}} \mathrm{kg}^{-1}\right.$ of Ca and $4.0 \mathrm{cmol}_{\mathrm{c}}$ $\left.\mathrm{kg}^{-1} \mathrm{Mg}\right)$ and dolomitic $\left(44.8 \mathrm{cmol}_{\mathrm{c}} \mathrm{kg}^{-1}\right.$ of $\mathrm{Ca}$ and $22.5 \mathrm{cmol}_{\mathrm{c}} \mathrm{kg}^{-1}$ of $\mathrm{Mg}$ ) limestones to increase soil $\mathrm{pH}$ up to 6.0. $\mathrm{KCl}$ was herein used as $\mathrm{K}_{2} \mathrm{O}$ source; it was applied to soil surface and incorporated to the soil before vine transplantations. Potassium fertilizer and limestone incorporation was carried out in two different stages. Half of each dose was applied to soil surface and incorporated to the soil based on the plowing technique. Subsequently, the second half of each dose was applied to the soil and incorporated to it based on the subsoiling technique. Young Chardonnay vines (grafted onto the $110 \mathrm{R}$ rootstock) were transplanted to the field in October 2011, they were spaced $1.0 \mathrm{~m}$ from each other and $2.5 \mathrm{~m}$ between rows (4000 plants ha ${ }^{-1}$ ). In November 2014, soil samples were collected in the $0-10$ and $10-20-\mathrm{cm}$ layers in the crop row of each plant. The soil was air dried and sieved $(2 \mathrm{~mm}$ mesh). Then, the exchangeable $\mathrm{K}$ was extracted (Mehlich-1 extractor) and determined in flame photometer. The exchangeable $\mathrm{Ca}$ and $\mathrm{Mg}$ (1 mol $\mathrm{l}^{-1} \mathrm{KCl}$ extractor) were determined through atomic absorption spectrometry (Tedesco et al., 1995). In March 2012, 2013 and 2014, three leaves were collected in the median part of each plant, dried in forced air-circulation oven at $65^{\circ} \mathrm{C}$, ground and subjected to total $\mathrm{K}, \mathrm{Ca}$ and $\mathrm{Mg}$ content analysis 
(Tedesco et al., 1995). In March 2012, the height of each plant was measured with measuring tape and the stem diameter $(10 \mathrm{~cm}$ above the surface of the soil) was measured with digital caliper. Winter pruning was carried out in July 2012 and 2013. The pruned material was dried in forced air-circulation oven at $65{ }^{\circ} \mathrm{C}$ and, subsequently, the dry weight was recorded for each year. Stem diameter was measured with digital caliper in March 2013.

\section{Management practices adopted in Experiments 1 and 2}

The espalier technique was the plant conduction system adopted in experiments 1 and 2. Winter pruning was performed on a yearly basis, whereas side sprout removal was conducted during summer. Plants such as bahiagrass (Paspalum Notatum), pega pega (Desmodium Affine Schltdl.) and ryegrass (Lolium Multiflorum) prevailed in the rows between vines. They were often grazed throughout the year and their waste was deposited on soil surface. The vegetation in the rows between vines was desiccated over the years with non-residual herbicide. Drip irrigation was annually performed in the two experiments from November to January. Two weekly irrigations were carried out, which totaled the addition of approximately of $22.75 \mathrm{~mm}$ water per week, per plant. The experimental design followed a randomized block design, with three repetitions; each experimental plot comprised ten plants distributed along the crop row. Evaluations were carried out in the eight central plants of each row.

\section{Statistical analysis}

Results of the two experiments were subjected to analysis of variance. Significant means in experiment 1 were compared in the Tukey test, at $5 \%$ probability level $(\mathrm{p}<0.05)$. Regression equations were adjusted to the means recorded in experiment 2 whenever the effects were significant. The best model was selected through the F test, at error probability lower than $5 \%(\mathrm{p}<0.05)$.

\section{Experiment 1}

The exchangeable $\mathrm{K}$ content in the $0-10-\mathrm{cm}$ soil layer of the vineyard planted with Chardonnay and Pinot Noir cultivars increased as the nutrient dose increased in 2014 (Table 2). However, the exchangeable $\mathrm{K}$ content in the 10-20-cm layer was not affected by the nutrient dose applied to the soil in the two vineyards. The lack of increased exchangeable $\mathrm{K}$ content in the $10-20-\mathrm{cm}$ layer may have happened due to partial $\mathrm{K}$ absorption by the roots, to its incorporation to the shoot tissue, to nutrient removal through the pruned material (Brunetto et al., 2006), as well as to $\mathrm{K}$ absorption by the roots and incorporation to the shoot tissue of plants cohabitating the vineyard (Zalamena, 2013; Brunetto et al., 2018). The deposition and decomposition of waste from plant species cohabiting the vineyard, along with the presence of senescent leaves of young vines on soil surface, may have released the $\mathrm{K}$ incorporated to the shoot tissue. This process may have helped maintaining or increasing the nutrient content in the most superficial soil layers, as seen in the exchangeable $\mathrm{K}$ content in the $0-10-\mathrm{cm}$ layer (Table 2) - similar results were already recorded for other nutrients (Ventura et al., 2010). The exchangeable K contents found in the 0-10 and 10-20-cm soil layers subjected to all $\mathrm{K}$ doses in vineyards planted with Chardonnay and Pinot Noir cultivars were much lower than the $80 \mathrm{mg} \mathrm{kg}^{-1}$ found in the soil before experiment implementation (Table 2). Based on this outcome, part of the $\mathrm{K}$ content in the soil may have been removed through the pruned material; however, part of the applied $\mathrm{K}$ may have migrated to soil layers lower than $20 \mathrm{~cm}$ over the years. It may

Table 2. Exchangeable K content in soil (February 2014) subjected to the application of K doses and cultivated with Chardonnay and Pinot Noir vines.

\begin{tabular}{clccc}
\hline & \multicolumn{4}{c}{ Dose $\left(\mathrm{kg} \mathrm{ha}^{-1}\right.$ of $\left.\mathrm{K}_{2} \mathrm{O}\right)$} \\
\cline { 2 - 5 } Layers $(\mathrm{cm})$ & 0 & \multicolumn{4}{c}{60} & $\mathrm{CV}(\%)$ \\
\cline { 2 - 5 } & \multicolumn{4}{c}{ Chardonnay } \\
\cline { 2 - 5 } & $29.0 \mathrm{~b}^{(1)}$ & $34.3 \mathrm{a}$ & $37.7 \mathrm{a}$ & 5.39 \\
\hline $0-10$ & $16.3 \mathrm{a}$ & $21.0 \mathrm{a}$ & $22.3 \mathrm{a}$ & 8.38 \\
\hline \multicolumn{5}{c}{ Pinot Noir } \\
\hline \multirow{5}{*}{$0-10$} & $28.8 \mathrm{~b}$ & $31.0 \mathrm{a}$ & $38.0 \mathrm{a}$ & 4.37 \\
$10-20$ & $15.0 \mathrm{a}$ & $18.0 \mathrm{a}$ & $21.0 \mathrm{a}$ & 6.55 \\
\hline
\end{tabular}

(1) Means followed by the same letter on the line do not differ from each other in the Tukey test, at $5 \%$ error. 
have happened because irrigations were annually carried out from November to January and it may have stimulated $\mathrm{K}$ ion displacement in the soil, mainly in soil presenting low $\mathrm{CEC}_{\mathrm{pH} 7.0}\left(4.7 \mathrm{cmol}_{\mathrm{c}}\right.$ $\left.\mathrm{kg}^{-1}\right)$. $\mathrm{K}$ displacement may also have happened in soil with history of limestone application, which increased $\mathrm{Ca}$ and $\mathrm{Mg}$ adsorption in functional groups of soil reactive particles and partly stimulated $\mathrm{K}$ displacement from the solid fraction to the solution (Werle et al., 2008; Ernani et al., 2012). Thus, it is necessary applying potassium fertilizer doses to the soil on a yearly basis, rather than just before vineyard implementation, in order to maintain $\mathrm{K}$ levels in the soil close to the original ones and in adequate amounts capable of meeting plant demands. The total $\mathrm{K}$ content in the leaves from Chardonnay and Pinot Noir (2011/12 crop) cultivars increased after the nutrient dose was applied to the soil (Table 3). This outcome can be explained by the increased exchangeable K content in the soil after the application of nutrient doses, as seen in the $0-10-\mathrm{cm}$ layer (Table 2). Thus, the diffusion process may have transported part of the K applied to the external surface of the roots, where it was later absorbed, transported inside the vines and accumulated in growth-related organs such as leaves (Tagliavini \& Scandellari, 2013). On the other hand, the total $\mathrm{K}$ levels in the leaves of Chardonnay and Pinot Noir vines (2012/13 and 2013/14 crop seasons) were not affected by the K dose and content in the soil. It may have happened because the exchangeable $\mathrm{K}$ contents in the soil decreased at all doses over the years in comparison to the initial $\mathrm{K}$ content in it $\left(80 \mathrm{mg} \mathrm{kg}^{-1}\right)$. Therefore, vine roots may have absorbed smaller $\mathrm{K}$ amounts from the soil. Consequently, it may have reduced the amount of this nutrient in the shoot tissue, fact that justified the equal $\mathrm{K}$ content in the leaves of

Table 3. Plant height, stem diameter, dry weight of the pruned material, and total $\mathrm{K}$ in leaves of Chardonnay and Pinot Noir vines, in the 2011/12, 2012/13 and 2013/14 crop seasons.

\begin{tabular}{|c|c|c|c|c|}
\hline \multirow{3}{*}{$2011 / 12$} & \multicolumn{3}{|c|}{ Dose $\left(\mathrm{kg} \mathrm{ha}^{-1}\right.$ of $\left.\mathrm{K}_{2} \mathrm{O}\right)$} & \multirow{2}{*}{$\mathrm{CV}(\%)$} \\
\hline & 0 & 30 & 60 & \\
\hline & \multicolumn{4}{|c|}{ Chardonnay } \\
\hline Plant height $(\mathrm{cm})$ & $42.1 \mathrm{a}^{(1)}$ & $52.9 \mathrm{a}$ & $43.1 \mathrm{a}$ & 25.32 \\
\hline Stem diameter $(\mathrm{cm})$ & $0.53 \mathrm{a}$ & $0.64 \mathrm{a}$ & $0.56 \mathrm{a}$ & 14.38 \\
\hline Weight of the pruned material $\left(\mathrm{kg} \mathrm{ha}^{-1}\right)$ & $89.6 \mathrm{a}$ & $114.8 \mathrm{a}$ & $94.6 \mathrm{a}$ & 22.54 \\
\hline Total $\mathrm{K}$ in the leaf $\left(\mathrm{g} \mathrm{kg}^{-1}\right)$ & $11.0 \mathrm{~b}$ & $15.2 \mathrm{a}$ & $13.7 \mathrm{a}$ & 10.0 \\
\hline \multicolumn{5}{|l|}{$2012 / 13$} \\
\hline Stem diameter $(\mathrm{cm})$ & $0.78 \mathrm{a}$ & $0.90 \mathrm{a}$ & $0.80 \mathrm{a}$ & 12.00 \\
\hline Weight of the pruned material $\left(\mathrm{kg} \mathrm{ha}^{-1}\right)$ & $61.2 \mathrm{a}$ & $121.2 \mathrm{a}$ & $78.8 \mathrm{a}$ & 35.00 \\
\hline Total $\mathrm{K}$ in the leaf $\left(\mathrm{g} \mathrm{kg}^{-1}\right)$ & $25.4 \mathrm{a}$ & $25.5 \mathrm{a}$ & $22.6 \mathrm{a}$ & 8.40 \\
\hline \multicolumn{5}{|l|}{$2013 / 14$} \\
\hline Total $\mathrm{K}$ in the leaf $\left(\mathrm{g} \mathrm{kg}^{-1}\right)$ & $12.6 \mathrm{a}$ & $9.6 \mathrm{a}$ & $11.6 \mathrm{a}$ & 8.30 \\
\hline $2011 / 12$ & \multicolumn{4}{|c|}{ Pinot Noir } \\
\hline Plant height $(\mathrm{cm})$ & $60.7 \mathrm{a}$ & $62.9 \mathrm{a}$ & $50.6 \mathrm{a}$ & 18.69 \\
\hline Stem diameter $(\mathrm{cm})$ & $0.57 \mathrm{a}$ & $0.57 \mathrm{a}$ & $0.45 \mathrm{a}$ & 12.19 \\
\hline Weight of the pruned material $\left(\mathrm{kg} \mathrm{ha}^{-1}\right)$ & $122.9 \mathrm{a}$ & $175.1 \mathrm{a}$ & $110.4 \mathrm{a}$ & 16.43 \\
\hline Total $\mathrm{K}$ in the leaf $\left(\mathrm{g} \mathrm{kg}^{-1}\right)$ & $10.2 b$ & $16.9 \mathrm{~b}$ & $11.1 \mathrm{~b}$ & 7.90 \\
\hline \multicolumn{5}{|l|}{$2012 / 13$} \\
\hline Stem diameter $(\mathrm{cm})$ & $0.84 \mathrm{a}$ & $0.87 \mathrm{a}$ & $0.87 \mathrm{a}$ & 49.00 \\
\hline Weight of the pruned material $\left(\mathrm{kg} \mathrm{ha}^{-1}\right)$ & $104.2 \mathrm{a}$ & $99.7 \mathrm{a}$ & $111.1 \mathrm{a}$ & 27.6 \\
\hline Total $\mathrm{K}$ in the leaf $\left(\mathrm{g} \mathrm{kg}^{-1}\right)$ & $28.4 \mathrm{a}$ & $28.7 \mathrm{a}$ & $27.1 \mathrm{a}$ & 9.24 \\
\hline \multicolumn{5}{|l|}{$2013 / 14$} \\
\hline Total $\mathrm{K}$ in the leaf $\left(\mathrm{g} \mathrm{kg}^{-1}\right)$ & $10.9 \mathrm{a}$ & $10.6 \mathrm{a}$ & $12.8 \mathrm{a}$ & 7.80 \\
\hline
\end{tabular}

(1) Means followed by the same letter on the line do not differ from each other in the Tukey test, at $5 \%$ error. 
vines grown in soils subjected to the application of different $\mathrm{K}$ doses. The lack of increase in $\mathrm{K}$ content inside Chardonnay and Pinot Noir vines grown in soil subjected to the application of $\mathrm{K}$ doses can be one of the explanations for the lack of increase in other plant parameters such as stem diameter and weight of the pruned material in the 2012/13 crop season (Table 3 ). $\mathrm{K}$ has functions associated with photosynthesis, osmotic potential maintenance and with enzyme reactions in plants (Conde et al., 2007; Fagan et al., 2016). Thus, it can indirectly affect vine-related growth parameters such as plant height, stem diameter and pruned material.

\section{Experiment 2}

The exchangeable $\mathrm{K}, \mathrm{Ca}$ and $\mathrm{Mg}$ contents in the $0-10$ and $10-20 \mathrm{~cm}$ soil layers were not affected by the application of $\mathrm{K}$ doses, in association with calcitic and dolomitic limestones (Table 4). The fact that the $\mathrm{K}$ content in the soil did not increase as the nutrient dose increased may be explained by its absorption, transport and removal through the pruning material of young vines (Brunetto et al., 2006; Brunetto et al., 2018). This process became evident when both soils subjected to calcitic and dolomitic limestone applications in the 2011/12 crop season enabled increased $\mathrm{K}$ content in vine leaves after the application of potassium fertilizer dose. It also indicated that the nutrient was absorbed by the plants, transported and accumulated in their shoot organs, mainly in the leaves, which presented intense cellular division during the vegetative period. Therefore, this process worked as strong $\mathrm{K}$ drain in the growing vines. Besides its removal through the pruned material, part of the $\mathrm{K}$ may have migrated to subsurface layers in the soil (Arienzo et al., 2009). On the other hand, the $\mathrm{K}$ content in the leaves of plants grown in the 2012/13 and 2013/14 crop seasons, as well as the $\mathrm{Ca}$ and $\mathrm{Mg}$ contents, were not affected by $\mathrm{K}$, calcitic and dolomitic limestone application (Table 5). This outcome can be attributed to the lack of increase in exchangeable $\mathrm{K}$ contents after potassium fertilization application, or even to the lack of increase in exchangeable $\mathrm{Ca}$ and $\mathrm{Mg}$

Table 4. Exchangeable $\mathrm{K}, \mathrm{Ca}$ and $\mathrm{Mg}$ contents in the 0-10 and 10-20cm layers (February 2014) of soil subjected to the application of $\mathrm{K}$ doses, calcitic and dolomitic limestones.

\begin{tabular}{|c|c|c|c|c|c|c|}
\hline & \multicolumn{4}{|c|}{ Dose, $\mathrm{kg} \mathrm{ha}^{-1}$ of $\mathrm{K}_{2} \mathrm{O}$} & \multirow[b]{2}{*}{ Equation } & \multirow[b]{2}{*}{$\mathrm{CV}(\%)$} \\
\hline & 0 & 60 & 120 & 180 & & \\
\hline & \multicolumn{6}{|c|}{ Calcitic } \\
\hline & \multicolumn{6}{|c|}{$0-10 \mathrm{~cm}$} \\
\hline $\mathrm{K}\left(\mathrm{mg} \mathrm{kg}^{-1}\right)$ & $33.7 \mathrm{a}^{(1)}$ & 30.0 & 37.0 & 41.3 & ns & 10.88 \\
\hline $\mathrm{Ca}\left(\mathrm{cmol}_{\mathrm{c}} \mathrm{kg}^{-1}\right)$ & 2.6 & 2.7 & 2.8 & 2.6 & $\mathrm{~ns}$ & 7.58 \\
\hline \multirow[t]{2}{*}{$\mathrm{Mg}\left(\mathrm{cmol}_{\mathrm{c}} \mathrm{kg}^{-1}\right)$} & 0.8 & 0.7 & 1.0 & 0.9 & ns & 8.98 \\
\hline & \multicolumn{6}{|c|}{$10-20 \mathrm{~cm}$} \\
\hline $\mathrm{K}\left(\mathrm{mg} \mathrm{kg}^{-1}\right)$ & 19.0 & 21.0 & 26.0 & 25.3 & ns & 9.61 \\
\hline $\mathrm{Ca}\left(\mathrm{cmol}_{\mathrm{c}} \mathrm{kg}^{-1}\right)$ & 1.9 & 1.9 & 1.5 & 1.6 & ns & 8.76 \\
\hline \multirow[t]{3}{*}{$\mathrm{Mg}\left(\mathrm{cmol}_{\mathrm{c}} \mathrm{kg}^{-1}\right)$} & 0.4 & 0.3 & 0.4 & 0.2 & ns & 8.55 \\
\hline & \multicolumn{6}{|c|}{ Dolomitic } \\
\hline & \multicolumn{6}{|c|}{$0-10 \mathrm{~cm}$} \\
\hline $\mathrm{K}\left(\mathrm{mg} \mathrm{kg}^{-1}\right)$ & 39.3 & 40.3 & 32.0 & 33.0 & $\mathrm{~ns}$ & 9.90 \\
\hline $\mathrm{Ca}\left(\mathrm{cmol}_{\mathrm{c}} \mathrm{kg}^{-1}\right)$ & 2.6 & 2.9 & 2.6 & 2.9 & ns & 7.60 \\
\hline \multirow[t]{2}{*}{$\mathrm{Mg}\left(\mathrm{cmol}_{\mathrm{c}} \mathrm{kg}^{-1}\right)$} & 1.3 & 1.4 & 1.0 & 1.3 & ns & 6.03 \\
\hline & \multicolumn{6}{|c|}{$10-20 \mathrm{~cm}$} \\
\hline $\mathrm{K}\left(\mathrm{mg} \mathrm{kg}^{-1}\right)$ & 22.3 & 28.7 & 25.3 & 27.5 & ns & 10.02 \\
\hline $\mathrm{Ca}\left(\mathrm{cmol}_{\mathrm{c}} \mathrm{kg}^{-1}\right)$ & 1.8 & 1.7 & 1.5 & 1.5 & ns & 8.99 \\
\hline $\mathrm{Mg}\left(\mathrm{cmol}_{\mathrm{c}} \mathrm{kg}^{-1}\right)$ & 1.0 & 1.0 & 0.8 & 1.0 & ns & 7.37 \\
\hline
\end{tabular}

$\mathrm{ns}=$ non-significant. 
Table 5. Plant height, stem diameter, total $\mathrm{K}, \mathrm{Ca}$ and $\mathrm{Mg}$ contents in the leaves of Chardonnay vines grown in soil subjected to the application of K doses, calcitic and dolomitic limestones in the 2011/12, 2012/13 and 2013/14 crop seasons.

\begin{tabular}{|c|c|c|c|c|c|c|c|}
\hline \multirow{3}{*}{$2011 / 12$} & \multicolumn{4}{|c|}{ Dose, $\mathrm{kg} \mathrm{ha}^{-1}$ of $\mathrm{K}_{2} \mathrm{O}$} & \multirow{2}{*}{ Equation } & \multirow{2}{*}{$\mathrm{R}^{2}$} & \multirow{2}{*}{$\mathrm{CV}(\%)$} \\
\hline & 0 & 60 & 120 & 180 & & & \\
\hline & \multicolumn{7}{|c|}{ Calcitic } \\
\hline Plant height $(\mathrm{cm})$ & 31.6 & 35.3 & 49.1 & 51.4 & ns & & 37.88 \\
\hline Stem diameter $(\mathrm{cm})$ & 0.35 & 0.39 & 0.52 & 0.51 & ns & & 9.96 \\
\hline Weight of the pruned material $\left(\mathrm{kg} \mathrm{ha}^{-1}\right)$ & 89.1 & 99.2 & 102.5 & 83.5 & ns & & 36.33 \\
\hline Total $\mathrm{K}$ in the leaf $\left(\mathrm{g} \mathrm{kg}^{-1}\right)$ & 8.6 & 13.4 & 14.4 & 14.2 & $1.067+0.002 x$ & $0.90^{*}$ & 12.30 \\
\hline Total $\mathrm{Ca}$ in the leaf $\left(\mathrm{g} \mathrm{kg}^{-1}\right)$ & 12.7 & 13.3 & 12.7 & 11.6 & ns & & 8.12 \\
\hline Total $\mathrm{Mg}$ in the leaf $\left(\mathrm{g} \mathrm{kg}^{-1}\right)$ & 3.7 & 3.8 & 3.8 & 3.3 & ns & & 9.90 \\
\hline \multicolumn{8}{|l|}{$2012 / 13$} \\
\hline Stem diameter $(\mathrm{cm})$ & 0.74 & 0.79 & 0.80 & 0.77 & ns & & 14.17 \\
\hline Weight of the pruned material $\left(\mathrm{kg} \mathrm{ha}^{-1}\right)$ & 45.7 & 46.9 & 48.1 & 61.8 & ns & & 89.00 \\
\hline Total $\mathrm{K}$ in the leaf $\left(\mathrm{g} \mathrm{kg}^{-1}\right)$ & 31.4 & 32.3 & 30.5 & 34.4 & ns & & 13.00 \\
\hline Total $\mathrm{Ca}$ in the leaf $\left(\mathrm{g} \mathrm{kg}^{-1}\right)$ & 5.6 & 5.4 & 5.2 & 6.5 & ns & & 8.00 \\
\hline Total $\mathrm{Mg}$ in the leaf $\left(\mathrm{g} \mathrm{kg}^{-1}\right)$ & 1.1 & 1.0 & 1.3 & 1.4 & ns & & 8.00 \\
\hline \multicolumn{8}{|l|}{$2013 / 14$} \\
\hline Total $\mathrm{K}$ in the leaf $\left(\mathrm{g} \mathrm{kg}^{-1}\right)$ & 11.9 & 17.6 & 17.6 & 21.0 & ns & & 15.08 \\
\hline Total $\mathrm{Ca}$ in the leaf $\left(\mathrm{g} \mathrm{kg}^{-1}\right)$ & 5.8 & 4.7 & 4.1 & 4.6 & ns & & 11.69 \\
\hline Total $\mathrm{Mg}$ in the leaf $\left(\mathrm{g} \mathrm{kg}^{-1}\right)$ & 1.3 & 0.9 & 1.0 & 0.7 & ns & & 9.7 \\
\hline $2011 / 12$ & \multicolumn{7}{|c|}{ Dolomitic } \\
\hline Plant height $(\mathrm{cm})$ & 48.9 & 42.0 & 35.7 & 42.9 & ns & & 10.64 \\
\hline Stem diameter $(\mathrm{cm})$ & 0.52 & 0.58 & 0.47 & 0.56 & ns & & 14.48 \\
\hline Weight of the pruned material $\left(\mathrm{kg} \mathrm{ha}^{-1}\right)$ & 98.6 & 74.0 & 65.1 & 75.8 & ns & & 21.74 \\
\hline Total $\mathrm{K}$ in the leaf $\left(\mathrm{g} \mathrm{kg}^{-1}\right)$ & 13.1 & 12.3 & 12.9 & 15.6 & $1.231-0.001 x$ & $0.65^{*}$ & 11.8 \\
\hline Total $\mathrm{Ca}$ in the leaf $\left(\mathrm{g} \mathrm{kg}^{-1}\right)$ & 12.8 & 8.9 & 11.1 & 9.9 & ns & & 11.99 \\
\hline Total $\mathrm{Mg}$ in the leaf $\left(\mathrm{g} \mathrm{kg}^{-1}\right)$ & 4.6 & 3.6 & 4.0 & 3.9 & ns & & 9.04 \\
\hline \multicolumn{8}{|l|}{$2012 / 13$} \\
\hline Stem diameter $(\mathrm{cm})$ & 0.81 & 0.80 & 0.64 & 0.68 & ns & & 8.55 \\
\hline Weight of the pruned material $\left(\mathrm{kg} \mathrm{ha}^{-1}\right)$ & 67.4 & 47.5 & 51.6 & 39.3 & ns & & 58.77 \\
\hline Total $\mathrm{K}$ in the leaf $\left(\mathrm{g} \mathrm{kg}^{-1}\right)$ & 26.2 & 30.7 & 30.3 & 34.1 & ns & & 9.22 \\
\hline Total $\mathrm{Ca}$ in the leaf $\left(\mathrm{g} \mathrm{kg}^{-1}\right)$ & 5.9 & 7.7 & 6.3 & 5.9 & ns & & 9.56 \\
\hline Total $\mathrm{Mg}$ in the leaf $\left(\mathrm{g} \mathrm{kg}^{-1}\right)$ & 1.5 & 2.3 & 2.0 & 1.6 & ns & & 9.00 \\
\hline \multicolumn{8}{|l|}{$2013 / 14$} \\
\hline Total $\mathrm{K}$ in the leaf $\left(\mathrm{g} \mathrm{kg}^{-1}\right)$ & 11.0 & 13.4 & 15.9 & 17.8 & ns & & 13.78 \\
\hline Total $\mathrm{Ca}$ in the leaf $\left(\mathrm{g} \mathrm{kg}^{-1}\right)$ & 3.6 & 3.9 & 3.5 & 3.9 & ns & & 10.21 \\
\hline Total $\mathrm{Mg}$ in the leaf $\left(\mathrm{g} \mathrm{kg}^{-1}\right)$ & 1.1 & 1.2 & 1.0 & 1.1 & ns & & 10.57 \\
\hline
\end{tabular}

ns $=$ non-significant $; *$ Significant at $5 \%$ probability level.

contents in the soil after dolomitic and calcitic limestone application. The 2011/12 crop season presented increased total $\mathrm{K}$ content in vine leaves as the $\mathrm{k}$ dose in the soil increased, and after the application of calcitic and dolomitic limestones. Thus, it was assumed that there was insufficient $\mathrm{K}$ absorbed by, and accumulated in, plants grown in other crop seasons (2012/13 and 2013/14). This outcome can partly explain the lack of impact of $\mathrm{K}$ addition, or even of $\mathrm{Ca}$ and $\mathrm{Mg}$ contents, on plant height in the 2011/12 crop, on stem diameter in 2012/13 and on pruned material in both crops; as well as the lack of calcitic and dolomitic limestone application impact on stem diameter and pruned material, respectively, in both crops. Most likely, the lack of increase in growth parameters of grapevine plants happened because $\mathrm{K}, \mathrm{Ca}$ and $\mathrm{Mg}$ do not directly affect plant growth, although 
their supply is essential to vital plant functions such as photosynthesis. Among the main functions performed by $\mathrm{K}$, it is worth highlighting that this nutrient helps maintaining the osmotic potential of plants, besides participating in several enzyme reactions in important metabolic routes. $\mathrm{Mg}$ is part of the chlorophyll molecule, whereas Ca works in plant protection, as well as in cell wall formation and stiffness. Thus, although no impact was observed on the herein evaluated plant parameters, the supply of these elements to the soil through potassium fertilization and liming is essential to help maintaining plant physiological processes
(Tagliavini and Marangoni, 2002; Pradubsuk and Davenport, 2010).

Potassium fertilizer application to the soil increased the $\mathrm{K}$ content in the $0-10 \mathrm{~cm}$ layer and enabled $\mathrm{K}$ absorption by plants, fact that was confirmed through the K content in the leaves of plants grown in the first crop season; however, it did not affect growth parameters in Chardonnay and Pinot Noir cultivars.K, dolomitic and calcitic limestone application enabled the best $\mathrm{K}$ absorption by plants, as it was confirmed through the highest $\mathrm{K}$ content observed in the leaves; however, it did not affect growth parameters in cultivar Chardonnay.

\section{Literature cited}

Arienzo, M.; Christen, E. W.; Quayle, W.; Kumar, A. 2009. A review of the fate of potassium in the soil-plant system after land application of wastewaters. Journal of hazardous materials, 154: 415-422.

Bachteler, K.; Riedel, M.; Merkt, N.; Ullrich, B.; Erhardt, M.; Jens, W.

2013. Effect of soil fertilization on the incidence of berry shrivel and the quality of resulting wine. Vitis, 52(1): 1-7.

Brunetto, G.; Garlete, L.; Ceretta, C.A.; Melo, G.W.B. De; Hammerschmitt, R.K.; Couto, R. Da R.

2018. Decomposition and release of nutrients from leaves and pruned stems in vineyard. Revista de Ciencias Agrarias/ Amazonian Journal of Agricultural and Environmental Sciences, 61. DOI:10.22491/rca.2018.2624.

Brunetto, G., Garlete, L., Ceretta, C.A.; Melo, G. W.; Hammerschmitt, R. K.; Couto, R.

2018. Decomposition and release of nutrients from leaves and pruned stems in vineyard. Revista de Ciências Agrárias/ Amazonian Journal of Agricultural and Environmental Sciences, 61. DOI:10.22491/rca.2018.2624

Christensen, P.

1991. The relationship of nitrogen and other elements to the bunch stem necrosis disorder 'waterberry'. In: International Symposium on Nitrogen in grapes and Wine. J. M. Rantz (Ed.). American Journal of Enology and Viticulture, Davis, CA, US. pp. 198-109.

Comissão de Química e Fertilidade do Solo RS/SC.

2016. Manual de adubação e calagem para os Estados do Rio Grande do Sul e de Santa Catarina. 10.ed. Porto Alegre, SBCS - Núcleo Regional Sul/UFRGS, 400 p.

Conde, C.; Silva, P.; Fontes, N.; Dias, A.; Tavares, R.; Sousa, M.; Agasse, A.; Delrot, S.; Gerós, H.

2007. Biochemical changes throughout grape Berry development and fruit and wine quality. Food, 1: 1-22.

Coombe, B.G.

1992. Research on development and ripening of the grape Berry. American Journal of Enology and Viticulture, 35: 40-45.

da Silva, A.C.; Rodrigues, E.A.G.

2018. A viticultura nas microrregiões do Rio Grande do Sul e sua distribuição locacional. Orbis Latina, 8(1): 05-20. de Melo, G.W.B.; Brunetto, G.; Ceretta, C.A.; Ciotta, M.N.; Zalamena, J.

2016. Capítulo 1 Adubação de pré-plantio e crescimento em videiras. In: Melo, G.W.B. de; Zalamena, J.; Brunetto, G.; Ceretta, C.A. Calagem. (Eds.). Adubação e contaminação em solos cultivados com videiras. Embrapa uva e Vinho. RS, Brazil. pp. 11-17.

Ernani, P.R.; Mantovani, A.; Scheidt, F.R.

2012. Liming decreases the vertical mobility of potassium in acidic soils. Communications in Soil Science and Plant Analysis, 43: 2544-2549.

Fagan, E.B.; Ono, E.O.; Rodrigues, J.D.; Soares, L.; Dourado Neto, D.; Andrei, E.

2016. Fisiologia vegetal: Metabolismo e Nutrição Mineral. Editora Andrei, São Paulo, Brasil, 306 p.

Hall, G.

2011. Loss of rachis cell viability is associated with ripening disorders in grapes. Journal of experimental Botany, 62: $1145-1153$

Mello, R.L.M.

2010. Vitivinicultura brasileira: panorama 2009. Bento Gonçalves: Embrapa Uva e Vinho (artigo técnico).

Pickering, A.H.

2005. Inter relationships between Vine vigours and the incidence of bunch stem necrosis in Cabernet Sauvignon grapevines. Venosa, Italy, Acta Horticulturae, $4 \mathrm{p}$.

Pradubsuk, S.; Davenport, J.R.

2010. Seasonal uptake and partitioning of macronutrients in mature 'Concord' grape. Journal of the American Society for Horticultural Science, 135: 474-483.

Santos, H.G. Dos; Jacomine, P.K.T;; Anjos, L.H.C. Dos; Oliveira, V.A. De; Lumbreras, J. F.; Coelho, M.R.; Almeida, J.A. De; Cunha, T.J.F.; Oliveira, J.B. de.

2013. Sistema brasileiro de classificação de solos. Embrapa. Brasília, DF, Brasil. 353 p.

Tagliavini, M.; Marangoni, B.

2002. Major nutritional issues in deciduous fruit orchards of Northern Italy. Hort Technology, 12: 26-31.

Tagliavini, M.; Scandellari, F.

2013. Methodologies and Concepts in the Study of Nutrient Uptake Requirements and Partitioning in Fruit Trees. Acta Horticulturae, 984, 47-56. 
Tedesco, M.J.; Gianello, C.; Bissani, C.A.; Bohnen, H.; Volsweiss, S.J.

1995. Análise de solo, plantas e outros materiais. 2. Ed. Porto Alegre-RS. Departamento de Solos UFRGS, 174 p. Toumi, M.; Nedjimi, B.; Halitim, A.; Garcia, M.

2016. Effects of K-Mg ratio on growth and cation nutrition of Vitis vinifera L. cv. 'Dattier de Beiruth' grafted on SO4 rootstock. Journal of Plant Nutrition, New York, 39(7): 904-911.

Ventura, M.; Scandellari, F.; Bonora, E.; Tagliavini, M.

2010. Nutrient release during decomposition of leaf litter in a peach (Prunus persica L.) orchard. Nutr Cycl Agroecosyst. 87, 115-125.
Werle, R. Garcia, R.A.; Rosolem, C.A. 2008. Lixiviação de potássio em função da textura e da disponibilidade de nutriente no solo. Revista Brasileira de Ciência do Solo, $32,2297-2305$.

Zalamena, J.

2013. Produtividade e composição de uva e de vinho de videiras consorciadas com plantas de cobertura. Pesquisa agropecuária brasileira, Brasília, 48, 182-189. doi: 10.1590/ S0100-204X2013000200008. 
